\title{
Introduction to the Special Series on the Digital Divide
}

\author{
Elizabeth C. Boyd \\ Publisher, Informing Science \\ Betty Boyd@acm.org
}

\section{What is the Digital Divide?}

Enter the phrase "Digital Divide" into a search engine and you receive hundreds of hits. What is this topic and why is so much attention being paid to it?

A number of definitions can be found for the term. The Web site http://whatis.techtarget.com explains that the term "describes the fact that the world can be divided into people who do and people who don't have access to - and the capability to use - modern information technology, such as the telephone, television, or the Internet...The digital divide also exists between the educated and the uneducated, between economic classes, and, globally, between the more and less industrially developed nations" (Digital Divide, 2002). The American Library Association (2002) stresses that it includes differences in both "access to information through the Internet, and other information technologies and services" and in "the skills, knowledge, and abilities to use information, the Internet and other technologies." According to the World Economic Forum (2002), "The issue of digital divide extends more broadly than merely that of direct access to technology. Instead, it can be conceived of as the disparity between how different nations are using information and communication technologies as a tool for social and economic development."

\section{Statistics}

The Digital Divide Network (2002) states that although there are an estimated 429 million people online globally, this represents only $6 \%$ of the world's entire population. "Even among highly developed nations, there exist vast differences in the availability of home Internet access. Sweden ranks as the nation with the highest percentage of

Material published as part of this journal, either on-line or in print, is copyrighted by the publisher of Informing Science. Permission to make digital or paper copy of part or all of these works for personal or classroom use is granted without fee provided that the copies are not made or distributed for profit or commercial advantage AND that copies 1) bear this notice in full and 2) give the full citation on the first page. It is permissible to abstract these works so long as credit is given. To copy in all other cases or to republish or to post on a server or to redistribute to lists requires specific permission and payment of a fee. Contact Editor@inform.nu to request redistribution permission. home Internet connections at 61\%; Spain trails the list with only $20 \%$ of its homes connected."

The International Labour Organization's World Employment Report 2001: Life at Work in the Information Economy found that "nearly 90 percent of all Internet users are in industrialized countries, with the United States and Canada alone accounting for 57 percent of the total. In contrast, Internet users in Africa and the Middle East, together account for only 1 percent of the global Internet users" (Pastore, 2001).

\section{Impact of the Digital Divide}

Informing Science explores issues in the use of information technology to inform clients. As information technology is fast becoming a major tool for disseminating and obtaining information, gaps between those who have access to this tool and those who do not is a major concern.

Many fear that if ways to bridge the Digital Divide are not found, the gap between the "haves" and the "have-nots" will increase, both within and among nations. According to the World Economic Forum (2002), although the mere presence of information and communication technology (ICT) "will not guarantee economic and social development, it is widely held that ICTs are tools that can enable a better quality of life. The ways in which ICT is developed, structured and used will influence how countries can reach their national capabilities and leapfrog some of the traditional barriers to development."

As Jesse Berst, (1999) Editorial Director, ZDNet AnchorDesk, wrote, "The irony [is that t] he very technology that could be a bridge to a better world may be denied the less fortunate."

\section{Articles in this Series}

In response to this concern, this series of articles discuss and give examples of projects to bridge the Digital Divide.

In the first article Rod Carveth and Susan B. Kretchmer describe the situation in Western Europe and discusses policy options for combating the divide. 
Carmen Joham uses the experience in Venezuela to illustrate the need for effective information and communication technology policies for developing countries.

Tom Butler gives a detailed description of how a program to bring information literacy to a disadvantaged population within an Irish city. He describes the types of roadblocks that can be encountered in creating such a project and some of the ways to get around them.

In his research, Mike Hart has focused on ways to attract more disadvantaged students at the University of Cape Town in South Africa into the Information Systems degree program.

In the final article, Wal Taylor and Stewart Marshall describe their work with a local city council in Australia to develop a community network using information technologies.

\section{References}

American Library Association. What is the digital divide? Accessed July 30, 2002 at http://www.ala.org/oitp/digitaldivide/what.html

Berst, J. (Nov. 3, 1999). Why the digital divide is your problem too. ZDNet AnchorDesk. Accessed July 30, 2002 at http://www.zdnet.com/anchordesk/story/story 4059.html

Digital divide Definition accessed July 30, 2002 at http://whatis.techtarget.com

Digital Divide Network. Accessed July 30, 2002 at http://www.digitaldividenetwork.org/content/sections/index.cf $\mathrm{m} ? \mathrm{key}=2$

Pastore, M. (Jan 24, 2001) Global digital divide still very much in existence. Accessed August 24, 2002 at http://cyberatlas.internet.com/big picture/geographics/article/0, $, 5911569351,00 \cdot \mathrm{html}$

World Economic Forum - Global Digital Divide Initiative. Accessed on July 30, 2002 at

http://www.weforum.org/site/homepublic.nsf/Content/Global+ Digital+Divide+Initiative 